Józef Jaworski

Tarnów

\title{
Prayer as an expression of love
}

\begin{abstract}
The article presents the issue of the conjunction of prayer and love, which constitutes the essence of prayer. Attention is drawn to the fact that the reflexive human nature is in demand for prayer, which was reflected in the culture of antiquity. The need and appropriate understanding of prayer in the Old and New Testament thought is emphasized, which is ultimately explained in the love manifested in Christ the Redeemer of Man. The analytical and critical as well as the historical methods are employed in this article.
\end{abstract}

\section{Keywords}

prayer, contemplation, mysticism, love, redemption, culture of antiquity.

\section{Introduction}

The internal relationship between prayer and love may be observed in all religions of the world. The Pelasgian deluge myth says that in the beginning was love.

The fundamental precept and message of Christianity is love, the paradigm of which is Christ's relation to the Church.

The motive for ultimate spiritual life is boundless love. It evolves in two closely interconnected directions. First and foremost, towards God, who loves us, and in a particular perspective, by God towards man, who was redeemed by Christ.

The present article accounts for this issue in the current state of affairs of the world in which, besides addressing God through prayer, there have been tendencies attempting to free the contemporary man from non-empirical 
longings, leading him to the world of illusion, which closes man in a hermetic space, isolated from the normally functioning human community.

The intrinsic relationship between prayer, and love, which constitutes its essence, as emphasized in this article, aims at enhanced solidarity and fraternity among people. These are particularly important at the present stage of the human history, stricken with anxiety and terrorism.

At the beginning of the paper, the issue of prayer understood as an imperative of the reflexive human nature, will be discussed, based on the example of ancient Greeks and Romans.

It will then analyse the intrinsic relationship between prayer and love in the Old Testament and the new law of love left by Jesus Christ - the Redeemer of Man.. Jesus Christ appears as the ideal of the prayer life, possible to follow not only by the saints indicated in the present article, but also by everyone striving for holiness in its fullness.

\section{Prayer as a postulate of the reflexive human nature, based on the example of ancient Greeks and Romans}

The subject of prayer has always been present and valid in the religious life of man, religion and prayer intrinsically entwined. It is evidenced thorough research and observations dating back to the beginning of the history of life and activity of man. Cultures of primitive peoples indicate this incredible interdependability between the deity or deities and humans in their everyday lives. Religion, worship, and prayer in particular ways had a significant place in the lives of those peoples. Therefore, religiology scholars, stress, in their research, that there is no evidence for any period in the history of humankind where there was no belief in God as a Supreme Being. Therefore, there was never any time,, without prayer expressed in any form. For this reason, man was given the name homo orans: man - a being that prays!

The intricate relationship between religion and prayer is an imperative of the reflexive human nature. This imperative is a moral obligation to worship God for creating man. There is evidence of this veneration in, for example, two hymns: the Egyptian hymn of Akhenaten. Amenhotep IV to the Sun, as well as the Israeli hymn about the creation of the world - Psalm $104 .{ }^{1}$

\footnotetext{
${ }^{1}$ Cf. S. Sojka, Obowiązek czci Boga na podstawie Psalmu 104, Lublin 2003.
} 
Prayer is rooted in the metaphysical structure of man as a being created in God's image, endowed with a mind and free will, able to commune with its Maker through contemplation accompanied by love. ${ }^{2}$

Ahistoricism, which is addressed here, is fully manifested in the Book of Genesis: "So God created man in His own image; in the image of God He created him; male and female He created them" (Genesis 1:27). However, the key to comprehending the timelessness of humanism and its essential content is the person of Jesus Christ in whom "apparuit benignitas et humanitas, Salvatoris nostri Dei" - "the kindness and love of God our Savior appeared" (Titus 3:4).

The word humanitas includes a very rich reality: humanness, human nature, humanity, human attitude towards someone, friendliness, kindness, education, propriety. $^{3}$

The equivalent of humanitas in the Greek lexicon are the terms: antropotes, which means 'humanness' or anthropopatheia - 'human sensitivity' ${ }^{4}$, paideia 'upbringing', kalokagathia - 'beauty resulting from good', or prepon - 'tact'.

While examining the semantic content of humanitas, it is worth noting two classic quotes: "What graceful a thing human is, if human he truly is" 7; "Homo sum; et humani nil a me alienum esse puto" - "I am human, and nothing of that which is human is alien to me".

In the world masterpieces - the Iliad and the Odyssey - we encounter a lot of values of an invariable and timeless character. Not only does Ares make his presence felt, Troy is on fire, but we also find wistful conversations of characters with their mothers, filled with parental love. In those epics, we come across examples of marital fidelity e.g. the always faithful Odysseus and Penelope, as well as ideas of forgiveness and hospitality translated into the concretum of life. Similarly, as Hippocrates is ascribed the principle of medical ethics for physicians "primum non nocere", three centuries earlier Homer is ascribed the

${ }^{2}$ Cf. S. Sojka, Contemplatio et imitatio Christi, Kraków 2006, p. 29.

${ }^{3}$ Cf. L. Winniczuk, Ludzie, zwyczaje i obyczaje starożytnej Grecji i Rzymu, part 1, Warszawa 1985, p. 7.

${ }^{4}$ Ibid.

${ }^{5}$ Aulus Gellius (II century BC, Roman writer), Noctes Atticae XIII, 17,1.

${ }^{6}$ L. Winniczuk, Ludzie, zwyczaje i obyczaje..., p. 7.

${ }^{7}$ Menander (342-292 BC, Athenian, comedy writer).

8 Terence, Roman comedy writer, freedman from Carthage, Heautontimorumenos, I 1, 25. 
timeless statement that "Every human seeks his own God, every human prays to his own God" (pantes anthropoi hiketeusin theon) - Odyssey 22, 322, (pantes anthropoi euchesthai theois) - Iliad 3, 296. ${ }^{9}$

Chryses, a priest of Apollo is described here with a Homeric word areter (praying, with a gift to say the proper prayer in a proper way); thus, prayer is his vocation and profession. ${ }^{10}$ The crowning achievement of Homer in this regard is the Hector's prayer for his son, combined with forgiveness (Iliad 6, 476-481).

It should also be noted that we may observe in Homer, the beginning of the internal relation between the internal and external activity, which should be present in the life of man. Phoenix, Achilles' tutor, taught him to be "a speaker of words and a practitioner of accomplished deeds". ${ }^{\text {"11 }}$

The Homeric words rheter and prekter may be juxtaposed with words in the Greek literature: theoraia and praksis to refer to 'words' and 'deeds', 'theory' and 'practice,' 'contemplation' and 'activity', 'reflection' and 'work. ${ }^{12}$

The essence of this issue may also be observed in mystics of all times and religions, who are characterized by striving towards unity with God - „unio mystica”. Such endeavours towards this unity are carried out in a variety of ways, one of which is contemplation. ${ }^{13}$

Ancient Greeks compared human life to a road whose final stage is heaven and eternal happiness consisting in uniting man with God and becoming similar to Him "homoiosis Theo". The condition for this similarity was the previous purgation of man by leading a virtuous life.

The role of the ancient Stoa was, according to Seneca, to prepare a person for contemplation. ${ }^{14}$ The reflexive human nature demands actions as well, as

9 Cf. H. Wójtowicz, Modlitwa w religii greckiej, „Tarnowskie Studia Teologiczne” (1981), vol. 8 , p. 26.

${ }^{10}$ Cf. H. Wójtowicz, Modlitwa w religii greckiej, p. 26.

11 Cf. Iliad 9,443.

12 Cf. H. Wójtowicz, Theoria i prasis u Orygenesa, "Roczniki Humanistyczne" 30 (1982), part 3, p. 65. See more on contemplation : S. Sojka, Contemplatio et imitatio Christi..., p. 27.

13 Cf. H. Wójtowicz, Rola modlitwy w mistyce w świetle wypowiedzi greckich Ojców Kościoła ze szczególnym uwzględnieniem wypowiedzi o modlitwie Orygenesa i Grzegorza z Nyssy, in: Mistyka w życiu człowieka, (ed.) W. Słomka, Lublin, 1980, p. 113.

${ }^{14}$ Cf. M. Babiński, "Actio" i "Contemplatio", w prozie Seneki Młodszego, mps BKUL, Lublin 1984, p. 13. See also : Etyczne aspekty „Actio i Contemplatio” w prozie Seneki Młodszego, „Roczniki Humanistyczne” 33 (1985), part 3, p. 28. 
stated by Seneca: "Natura nos ad utrumque genuit, et contemplationi rerum et actioni". ${ }^{15}$ This thought was also shared by the Roman trends in mysticism. ${ }^{16}$

While regarding the timeless contents of the ancient culture of Greeks and Romans such as: love in family, marital fidelity, faith in God and immortal life, prayer and striving for communion with God, by leading a righteous and virtuous life, it difficult not to mention the interpersonal relations, marked by humanism and propriety.

It is also worth mentioning the law of hospitality towards foreigners whose patron was Zeus 'Xenios', the law of begging as well as the idea of forgiveness.

In the context of what has already been said concerning the culture of the antiquity, it is worth posing a question which bothers the contemporary heirs to this culture and it regards its perfection and imperfection.

The answer to this query may, to some extent, be found in the following reflection of L. Winniczuk, who has already been mentioned in this paper: "Throughout centuries, the world has been fascinated by ancient Greece and Rome. We have admired the excellence of Greek thought, which has taught us to seek beauty; we have been enraptured by flawlessness of Romans as citizens, heroes, and lawyers. But in all this perfection, was everything really perfect? Were there no antagonisms, intrigues, offences, crime? What about slavery? What about the attitude towards the poor, who had to resort to selling themselves into slavery to the rich in order to pay off the debts? What about infanticide regulated by the law as the right to abandon infants?" (...). Therefore, we do not deal with the Greco-Roman culture because it was «ultimately perfect» but because with its imperfection, it led to perfect later centuries. ${ }^{17}$

It may thus be concluded that the perfection of the culture of antiquity is complemented by Jesus Christ.

Jesus Christ is the perfect image of the invisible God. Man was created in this image, as a creator of culture, thus, culture is understood as a result of his activity, branded by marks of ethical good, truth, beauty, and, above all, love, may acquire a certain degree of timelessness; these marks are sometimes referred to

15 De otio 5,1.

16 S. Sojka, LXXX Zjazd Polskiego Towarzystwa Filologicznego, „Vox Patrum” 4 (1984), part 6-7, pp. 470-474.

17 Cf. L. Winniczuk, Ludzie, zwyczaje i obyczaje..., pp. 5-6. 
as 'the Platonic Great Triad'. However, in Christianity, theologians regard Good, Truth and Beauty as God's attributes, or even His names. ${ }^{18}$

Humanitas and its synonyms discussed above, was accomplished by Jesus Christ when $\mathrm{He}$ came into the human history with its all turbulences, came into the changeability of time, came into 'all that is human', came into the whole human culture, delivering the truth about the Kingdom of Heaven. ${ }^{19}$

In the person of Jesus, the Redeemer of Man, eternity encountered the volatility of time, mystery came into contact with history, the divine knowledge touched the human knowledge; we may know His history but He is also above history. He is from a different world but simultaneously from our world. ${ }^{20}$

\section{Prayer in the circle of love}

Before examining the intricate relation between prayer and love, the theological principles of Christian love will be laid down. Christian love can be considered as a fundamental divine right deriving from the fact of creation and redemption. Possible areas of living out this love in everyday life can be discussed with reference to Jesus Christ, who is the ultimate ideal of this implementation. At the same time "Prayer is a gift from God, an answer to something which was, as it were, put into the mouth and deeds of man but simultaneously remains a free human act. The love of God mobilizes for prayer not only a particular 'organ of prayer' e.g. soul, but the whole man. The entirety of the person prays in its psychophysical unity, involving the intellectual, emotional, volitional, operational sphere in the contact with God. In various forms of prayer, we may be more engaged in thinking or imagination, feelings or acting, but prayer is always a personal act in which, starting from simply concentrating our attention on God or kneeling, a person addresses the person of God, thus expressing personalism of prayer". ${ }^{21}$

Love is the greatest commandment of God. All man's thoughts, words and deeds should express this love. The Ten Commandments precisely define which

18 Cf. M. Heller, 10.30 u Maksymiliana, Kraków 2014, p. 52.

19 Cf. Jezus Chrystus. Historia i Tajemnica, (eds.) W. Granat, E. Kopeć, Lublin 1982, p. 16.

${ }^{20}$ Cf. Jezus Chrystus. Historia i Tajemnica, (eds.) W. Granat, E. Kopeć, Lublin 1982, p. 16.

${ }^{21}$ E. Osewska, Rozwój religijności człowieka ze szczególnym uwzględnieniem rozwoju modlitwy, in: Dzisiejszy katecheta. Stan aktualny i wyzwania, (ed.) J. Stala, Kraków 2002, p. 313. 
actions manifest love to God and people, and which actions destroy it. He who loves God is the one who does God's will. Therefore, a person must constantly consider whether they have taken a course according to the will of Heavenly Father or according to their own desire. The Christian view of the world is one which is able to perceive in it the image of real love. Only love can see love. For numerous observers, the true face of love is invisible or comes down to an interpretation of it. "Only he who knows from experience what love has to say, comprehends love. It does not only involve developing a taste or educating our mind; it concerns the full initiation of soul. In it, the conscious evasion of the object disappears and is replaced with binding Myself with another, who is more than just somebody known to me and bestowed upon me by God". ${ }^{22}$ If Augustine's statement Credo ut intelligas refers predominantly to theology, the Christian vision of society is guided by another variant Ama, ut intelligas. It believes in and sees more the love itself.

St. Paul, in the Epistle to the Galatians, addresses the issue of love. The statement that the fruit of the Spirit is love constitutes a counterbalance to behaviours which are fruit of the flesh. One cannot be a good Christian and not live the Christian way. Performing acts of love for our neighbours is nothing more than just repaying the debts owed to God, who shows His love through the death of His Son for us. By His death and resurrection, Jesus became the Lord of the dead and the living. "This, in turn, demands - owing to the Lord and Saviour - an appropriate attitude in everyday conduct". ${ }^{23}$ Conscious of Jesus' love, we cannot mistreat it and defile ourselves as we are part of the body whose Head and bond is God.

St. Paul, when speaking of love, "starts at its source, that is God's love, which was revealed through Jesus Christ. Whereas His love is poured into our hearts through the Holy Spirit". ${ }^{24}$ Christian love in the absolute sense, is among the most significant values in the catalogue of virtues, even fundamental to other behaviours. The hymn extolling love refers to its defining characteristics. The first characteristic says that love is magnanimous and patient. The second attribute is kind-heartedness, i.e. sharing good with others. Love does not envy - which means it does not know jealousy, it is glad about someone's success. Love does not seek glory - does not like to shine. Love does not "puff up with pride" in

22 J. L. Marion, Communio w stużbie kultury miłości, “Communio” (1992) 5, p. 34.

${ }^{23}$ J. Łach, "Owocem Ducha jest miłość" (Ga 5:22), "Communio" (1995) 5, p. 28.

${ }^{24}$ Ibid., p. 29. 
interpersonal contacts, is not condescending. A loving one does not disrespect, does not allow for bad conduct violating decency "the end does not justify the means". Love does not search for its own fulfilment, i.e. it does not seek out own interests. It can be concluded that St. Paul prefers radical rules which eradicate egoism. He who truly loves, does not become irritated, remains calm and composed in the face of being wronged, does not harbour a grudge, does not suspect anybody of ill intentions, does not crave for vengeance and defends the wrongdoer, since "where love is the rule of conduct, the Holy Spirit himself acts and sets us, free from the power of darkness, leading us into the kingdom of His beloved Son". 25

In the Old Testament interpretation, the norm for conduct had been love for your neighbour and hatred for your enemies. The new norm bestowed upon us by Jesus was loving your enemies and praying for them: "If you love those who love you, what reward will you get? Are not even the tax collectors doing that? And if you greet only your own people, what are you doing more than others? Do not even pagans do that?". ${ }^{26}$ In the Gospel according to Matthew, the commandment to love our enemies (Matthew 5:43-48) reads as follows: "You have heard that it was said, 'Love your neighbour and hate your enemy. But I tell you, love your enemies and pray for those who persecute you, that you may be children of your Father in heaven." ${ }^{27}$ It also explains that the sun shines the same on the righteous and the unrighteous ones; it also rains the same on the former and the latter. The commanded love is to have the highest possible reach. It does not even exclude those who are enemies to God and His deeds. It is possible to keep the commandment of love for our enemies and it must be kept by all followers of Jesus and His teachings.

Jesus' lesson of love referred to what had been proclaimed in the Old Testament. Primarily, Jesus combined the previously separate commandments of love for God and the neighbour. He created a foundation for the entire Christian morality from these two commandments. To love God - is the most vital matter to man. The duty to love our neighbours is also important. Jesus Christ expanded the notion of the neighbour. A neighbour is every human,

25 J. Łach, "Owocem Ducha jest miłość" (Ga 5:22), "Communio" (1995) 5, p. 30.

${ }^{26}$ J. Łach, Obowiązek pojednania i miłości (Matthew 5:43-48), "Ruch Biblijny i Liturgiczny" (1986) 1-6, p. 234.

27 J. Łach, Relacja "złotej zasady postępowania" (Matthew 7:12) do nakazu miłości nieprzyjaciół (Matthew 5:43-48), "Ruch Biblijny i Liturgiczny” (1988) 6, p. 460. 
even enemy, whom we are obliged to address with love. Jesus instructed His disciples and followers to also love their enemies. He also commanded showing love by forgiving them as many times as someone wrongs us. In the teaching of Jesus, love is something completely different from love spoken of by Jews. Love, according to Jesus, does not refer to a nation anymore, as in the Old Testament, but to an individual human being. The most novel idea, however, was the act performed by Jesus, who laid down his human life out of sacrifice to God for people's sins, and as a testimony of His great love to them. ${ }^{28}$

The commandment of love, named "the great commandment" by Jesus (Cf. Matthew 22:36-40), used to be understood as referring solely to God and another human. Nonetheless, God's commandment also refers to love oneself, since it is to be a measure of love of our neighbours. Despite its apparent selfevident nature, it is not, however, an easy undertaking. One's love of oneself can easily be mistaken for egoism and self-idealization. To love oneself does not, therefore, mean striving to satisfy one's own needs and falling into selfadmiration but is related to finding oneself and constantly caring for humanity for which Jesus gave His life on the cross. Thus, to love oneself means "making every effort to become the most beautiful version of oneself, to bring out our entire wealth of beauty, kindness, sensitivity, resilience and hope". ${ }^{29}$

Apostleship, which is a brave testimony of Christ and His teaching, requires concrete evidence in the form of works of mercy. Therefore, it cannot come down to merely repeating and spreading articles of faith to others, which appear vain and grandiloquent when presented not in the context of an authentic attitude of love towards another human. An example of such an apostle of action is Fr. J. Beyzym, who in the name of love of God and man, devoted his life to serving lepers. Fr. Beyzym's concern for the good - particularly of "the spiritual nature of others, their salvation, is nothing other than apostleship. Beyzym's dedication to the sick was based on the fact that in every single one of them, he saw Jesus Christ, who suffers for the redemption of the world". ${ }^{30}$

Genuine love is "love of kindness", which is deeply ingrained in liking and friendship. It consists in mutual desire for everything which is good for the loved one, regardless of our own good. Karol Wojtyła wrote: "love, being a matter of our

${ }^{28}$ Cf. F. Gryglewicz, Problemy miłości w Nowym Testamencie, "Ruch Biblijny i Liturgiczny" (1974) 4-5, p. 260.

${ }^{29}$ M. Dziewiecki, Komunikacja wychowawcza, Kraków 2004, p. 170.

${ }^{30}$ J. Misiurek, Historia i teologia polskiej duchowości katolickiej, vol. 3, p. 20. 
inner life and spirit, greatly perfects its subject, it fills its existence as well as the existence of the person towards whom it is directed" ${ }^{31}$ Its most vital component is mutual devotion. Liking and friendship are also important. Love is a process of transforming liking into close friendship. It is a condition for creating love of devotion, i.e. betrothed love. Love between a man and a woman is participating in the most natural communion, which is part of being human. Betrothed love was regarded as an image of the human soul's love of God or the one love, which fills the life of the Holy Trinity and, at the same time, is a source of existence, salvation and divinization of the world.

The essence of Christian responsibility, resulting from following the commandment of loving our neighbour, is to bestow upon another human the kind concern for them. as parents have for their children's spiritual and moral development. To be responsible for someone means to take very good care of them, to teach them to make the kind of life decisions which will guide them to the only and the highest Good - God. To be responsible is finally to believe in another human being and have confidence in them. The essence of responsibility is accurately accounted for by J. Hudzik, who emphasizes that "it is necessary to back someone up, to stand up for someone, to put our authority, sometimes even our health (life) and wealth, on the line. And all of this knowing that we literally cannot «replace» that person, that we are not ultimately confident of that person's intentions, expectations or readiness to show gratitude. Thus, responsibility, by definition, cannot be driven by hope for self-actualization". ${ }^{32}$

Philanthropy and selfless help provided to the poorest, serves as an authentic manifestation of the Christian agape. It is not, however, an easy way to following the commandment of love since the awareness of Jesus' presence in the humiliated and the destitute, may sometimes be distorted by the attitude of resignation resulting from the conviction that aid rendered to one human being is not going to make a difference. Therefore, there is a need for people whose lives will serve as an example for the profound meaning of philanthropy. In the $20^{\text {th }}$ century, people were called to showing love to the needy by two great figures: Princess Diana Spencer and Mother Theresa of Calcutta. The latter remained in the shadow of the Princess, who was popular and adored by

${ }^{31}$ J. Gułkowski, Miłość i czyn Karola Wojtyły - precyzacje antropologiczno-etyczne, "Novum" (1979) 1, p. 32.

${ }^{32}$ J. Hudzik, Rozum - wolność - odpowiedzialność. Studium z historii idei w nowożytnej i współczesnej myśli filozoficznej, Lublin 2001, p. 303. 
the media and "who only to some degree conveyed the values to which Mother Theresa devoted her entire life, but she did it in front of the eyes of millions". ${ }^{33}$

This attitude is largely based on the stance of God Himself, who is always an advocate of the poor and the disadvantaged. The same approach ought to be shared by every Christian. Popes define this attitude in such notions as: social love, civilization of love, solidarity with impoverished people and preferential love of the poor, i.e. "a special form of preferential practice of Christian love towards the poor, attested by the entire tradition of the Church"34. This standpoint towards the destitute has inspired the Church to its comprehensive activity since its beginnings. To this day, the Church establishes new institutionalized forms of care for the poor, centered around abbeys, monasteries, fraternities, kindergartens, orphanages, hospitals, care and day-care centres, which provide support for people left with no means of subsistence. Activity of this sort has become an attribute of the Church since it aides thousands of the economically underprivileged, in conformity with its attitude of preferential love, which the Church has adopted.

Love expands a heart to such an extent that there is space for everyone, even those who do not understand or reciprocate love. This kind of love can only be learnt from Jesus and only from Him can one learn not to judge the inner intentions of people. A human may perceive only a few external indications, which, in many cases, hide the true motives for people's actions. Even if we see something evil, we should not judge the person immediately but, following the example of St. Bernard, defend them in our hearts. As long as we judge others, we have no right to demand justification for ourselves. If, in everyday relations with others, we were able to be understanding, many misunderstandings would become love, since this understanding enables us to take a friendly attitude towards others and look at others with kindness. Only a humble person is capable of understanding and respect for other people. For such a person, finding justification for faults of others is an easy and a natural task as they don't become shocked by it. "Let us not dwell too much on the flaws of others - as stated by St. Augustine - only in so much as to be able to help them". ${ }^{35}$

${ }^{33}$ Czy koniec kryzysu? Survey: Hertz P., Jedlicki J., Kula M., Legutko R., Łubieński T., Paczkowski A., Pociej B., Strzembosz T., Tazbir J., Turowicz J., Zanussi K., "Więź” (1998) 2, p. 27.

${ }^{34}$ L. Dyczewski, Kościół katolicki wobec ubóstwa, "Zeszyty Naukowe Katolickiego Uniwersytetu Lubelskiego" 1-2 (1996), p. 79.

35 C. F. Fernandez, Przebaczać i usprawiedliwiać, "Currenda” (1996) 4, p. 648. 
The criterion of final judgement, and dividing people into the just and wrongdoers will be love, hence, we will be judged by love. So many times, we have asked God for forgiveness, for mercy in a situation when we stray from the straight and narrow path, when we go astray. Nevertheless, we must bear it in mind that one day, we will meet God, the Judge, who will show us justice. Therefore, not only should we accept God's mercy but also show it to others since the way to eternity leads through man. We may find thousands of examples manifesting the true meaning of mercy and love towards other people; we may find numerous examples of how difficult this way is. Still, we may also see clearly how fruitful it is: "We earn God's judgement through our deeds of love. May we hear Christ's words at the end of our days, at the end of time "Come, you who are blessed by my Father, inherit the kingdom prepared for you from the foundation of the world» (Matthew 25,34)".36

The Christian religion is measured by the depth of our heart, which means that it is measured by our love. Saint John of the Cross once said: "in the evening of life we will be judged on love alone". It means that only love matters and that, in the future, we will account for love to God. God demands of man not only love but also everyday sanctity. For at judgment, it will become apparent what true and authentic love and sanctity we lived. This judgment will also be a report on our attitude towards others. St. Matthew lists good deeds which will manifest our love to God and man. Love of another man is not only bestowed upon us but also required of us. Our attitude should always be one with Jesus-God, since there will be so much greatness in us as there will be love to another man. ${ }^{37}$

\section{Love as an expression of redemptive love}

The teaching of Jesus was intended to make everyone adopt the perfect love - to God, neighbour and oneself. ${ }^{38}$ When leaving to His Father, in glory, Jesus left us, without a doubt, an unattainable ideal. This ideal, however, can be pursued

${ }^{36}$ I. Dec, Uroczystość Chrystusa Króla, Bóg miłosierny i sprawiedliwy, "Wrocławski Przegląd Teologiczny" (2002) 1, p. 264.

37 Cf. S. Grzybek, "Pod wieczór życia sądzeni będziemy z miłości", "Ruch Biblijny i Liturgiczny” (1979) 1-6, p. 62. More on this, see: S. Sojka, Modlitwa droga do świętości, Tarnów 2011.

${ }^{38}$ Cf. D. Zimoń, Uczestnictwo wiernych we mszy św. w duchu liturgii na ziemiach polskich w XIX wieku, p. 83. 
by every man "in accordance with the faith God has distributed to each of you" (Romans 12:3). ${ }^{39}$ The school of Christian life in the life of the redeemed is mainly prayer. Jesus the Redeemer proclaimed what was significant and central to the Law and Prophets of the Old Testament - the commandment of love, which is the commandment leading to perfection..$^{40}$ Jesus has, therefore, founded a new cult - a spiritual, existential cult: "Not only did He teach that the cult of the messiah hour will be a filial worship, devoted to God in the Holy Spirit, but $\mathrm{He}$ himself praised the Father in this way. ${ }^{41}$

Humans, endowed with the grace of redemption, achieve the ultimate prayer not when they express themselves but when Jesus becomes fully present in them as the Redeemer. To pray means to acknowledge that the grace of redemption exists, that everyone is to receive it and that it is available for everyone. It is a grace from which, as it were, the new world was born and which wishes to embrace every man at every moment of human history. Raising our spirit to Jesus the Redeemer is an expression of adoration: in the prayer of veneration and thanksgiving, in the prayer of intercession and beseeching. Prayer is an indispensable condition of obedience to the grace of redemption since we "should always pray and not give up (Luke18:1).

The grace of redemption is able to reach, through prayer, even to the hidden roots of iniquity so that it may guide humans to return to the right path, induce them to communion with God and people. A Christian is supported by the presence of Jesus Himself and the mystery of redemption, which is the source of piety. The prayer of the redeemed encompasses both God's love of man, as well as man's response to this love. The grace of redemption has the power of conversion and communion so that every human could face every iniquity and sin, in order to draw strength to live in accordance with the Gospel.

The motive for prayer in the lives of the redeemed is the absolute goodness of God. The absolute goodness of God means that God, in Himself, is good, regardless of the fact that $\mathrm{He}$ is goodness for beings (they may reject God) or not. In return for God's goodness, manifested in the act of redemption, there is, in particular, the adoration prayer during which the redeemed man open themselves up to Divine Mercy.

${ }^{39}$ Cf. J. Kutnik, Litania Loretańska, p. 184.

${ }^{40}$ Cf. C. S. Bartnik, Dogmatyka katolicka, vol. 1, p. 472.

${ }^{41}$ J. Kudasiewicz, Kult Ojca w Duchu i prawdzie a szczególna cześć Maryi, in: Matka Jezusa pośród pielgrzymującego Kościoła, (eds.) J. S. Gajek, K. Pek, Warszawa 1993, p. 129. 
To worship God means to open oneself up to Divine Mercy, which has become the source of redemption. The Church constantly reminds, in its teaching, that we need to learn how to devote time to God. Even when our life is hectic, we ought to find time for prayer as a form of adoration. For, to pray means to offer God time and oneself. We need to stop for a moment and listen. During our adoration, prayer forms a tight bond with Jesus the Redeemer since adoration is, in a way, an act of directly recognizing His Divine power. Therefore, we must not become disheartened, we must pray, persevere, since "adoration is a bond of love which is built through perseverance". ${ }^{42}$

The prayer of beseeching, thanksgiving and request, also puts man "face to face" with Jesus the Redeemer. During this meeting, man realizes that there is an inextricable connection between the grace of redemption and sanctity. By relating the grace of redemption to the call to holiness, Jesus defined a new horizon for the Christian worship, defined a new meaning of prayer. In comparison with the cult of the Old Testament, Jesus "did not desire the worship of a temple but the appropriate understanding of worship through the priestly hierarchy of Jerusalem; in other words, He wishes worship to compensate for Israel's sins, thus, for it to be an authentic disposition to receive the salvific gift of Jesus". ${ }^{3}$

Taking into account the teaching and paragon of Jesus, we may argue that one is a Christian to the extent that one wants want and is able to pray. Prayer must be continually studied. It is a task always ahead of man. Faith determines the intensity and content of prayer. If faith changes the mentality of man and commands them to put God first, as it develops, prayer will also become increasingly a sign of receiving the grace of redemption. Man thoroughly comprehends, through prayer, that mercy, which was revealed to us through His life by the Son of God, was the redeeming mercy.

Jesus the Redeemer has fulfilled God's plan of mercy. ${ }^{44}$ For this reason, $\mathrm{He}$ proclaimed love to be the new law of redeemed humanity. ${ }^{45} \mathrm{He}$ died, giving His

${ }^{42}$ M. Gołąb, Modlitwa adoracyjna (Wierność w modlitwie - wiernościa samemu Bogu), “Życie Konsekrowane” 1 (1999), p. 42.

43 J. J. Ferreira de Farias, Chrystocentryczny wymiar nadziei, "Communio" 1 (1991), p. 48.

${ }^{44}$ Cf. A. J. Nowak, Osoba konsekrowana, vol. III: Ślub czystości, Lublin 1999, p. 109.

45 "Christ is a sacrament, that is a visible and effective sign of God's love to man, and simultaneously a way of the redeemed man to the house of Father". K. Kupiec, Być duchownym, in: J. Królikowski, K. Kupiec, Święte posłanie. Z teologii kapłaństwa, Tarnów 2005, p. 167. 
life as the ultimate act of love and obedience - for the salvation of humankind. ${ }^{46}$ On His own volition, out of love, He made His life a sacrifice for the Father and brothers, so that the Father's love was present in them through Him. ${ }^{47} \mathrm{He}$ took the whole human life to transform it into the way of eternal life. ${ }^{48}$ All this may, and should be 'learnt', by the redeemed man in the school of prayer.

The spiritual life means, among other things, to overcome an emerging difficulty - one of choice between prayer and action. Both these forms of Christian life are interdependent and complementary to each other. The life of prayer, in a way, depends on the active life as in the material surface and a necessary disposition. There is no life of prayer without little deeds since prayer is such a little deed itself. When the active life and prayer achieve unity and harmony, then a Christian becomes spiritually mature.

A special area of the school of prayer in the life of the redeemed is contemplation. A Christian having no understanding of the contemplative life is probably affected by its false connotations. Love lies at the foundations of the contemplative life. Love, which man has for God, encompasses all people, who are called by God to participate in life. Thus, deeds of love and mercy towards our neighbours constitute a vital ingredient of the contemplative life. This life, in itself, is directed at deeds of love. The subject of contemplation and action is the same: Christ in Himself and in others. ${ }^{49}$

Certainly, it is paramount that there exists an appropriate proportion between praying and acting, so that there is the evangelical harmony between them. This ensures that contemplation is regarded as the highest spiritual state of human life on Earth. It is thanks to it that the soul is elevated to the highest level of connection with God, and simultaneously, it does not lose its cognitive and volitional capabilities, which are activated in new forms and at an even higher intensity. Man, endowed with the gift of contemplation, achieves a high degree of supernatural understanding of Gods actions, which exceeds all achievement

46 " Christ suffered out of love and obedience and gave more to God than was required by the compensation for sins of humankind: firstly, because of the vastness of Love shown in suffering, secondly, because of the dignity of His life, which He had given as the compensation (and this life was one of God-man), thirdly, because of the depth of suffering and the enormity of the endured pain". W. Granat, Dogmatyka katolicka, vol. IV, p. 78.

${ }^{47}$ Cf. G. Ricciotti, Życie Jezusa Chrystusa, Warszawa 1956, p. 580.

${ }^{48}$ Cf. A. L. Szafrański, Wierzyć w Chrystusa i żyć Eucharystia, p. 259.

${ }^{49}$ Cf. S. Urbański, Kontemplacja i działanie w życiu chrześcijanina, "Roczniki Teologiczne" 5 (1998), pp. 31-47. 
gained via discursive, and even intuitive reasoning. Contemplation leads to unifying man with God, which will be at its fullest only in the eternal life. ${ }^{50}$

Christian life, as a response to the grace of redemption, is to be a synthesis of contemplation and action. Therefore, the apostolic activity ought to originate in the internal unification with Jesus Christ. We need to learn how to combine contemplation with action, bearing in mind that we are collaborators of God. The Holy Spirit is the source of both contemplation and actions since contemplation is "clinging to God with our thought and heart". ${ }^{51}$ Contemplation is a means for achieving communion with God and within it, love to God and our neighbours, matters the most. The contemplative dimension of the life of a Christian is, thus, strictly connected with the redemptive (sanctifying) mission of the Church.

Spiritual life is a distinctive participation in the mission of Christ; in His concern for the salvation of the world. Apostolate constitutes a significant part of the response to the redemptive grace. An apostle is meant to persevere in Jesus the Redeemer and give a testimony of faith and love. Saint Thérèse of the Child Jesus may be considered an example of such a testimony, she felt that her actions resulting from receiving the gift of redemption should be directed at persons who are particularly abandoned and impoverished. She really wanted to aid them and pray for them: "I wish to be here, in great closeness to Jesus, I want to pray for sinners and devote my life to them".52 She wanted to win people's hearts over with her valiant attitude in order to teach them the great love to Jesus and give them strength to be victorious against all odds. She was of the opinion that sacrifices, prayers are not enough. We must spare no effort to discover 'the secret'. For that, we need intensive activity, as well as suffering and hardships: "It is not pure passivity, as it is generally believed, but it in itself is a driving force of the entire activity in the Church, moreover, it is the source of all of its fecundity" ${ }^{53}$

St. Thérèse perceived contemplation in her own peculiar way - she treated it as the greatest effort which can be imagined in Christianity. She was overflowing

${ }^{50}$ Cf. S. Urbański, Kontemplacja wlana, "Częstochowskie Studia Teologiczne” XIV (1986), p. 159.

${ }^{51}$ T. Gocłowski, Jedność kontemplacji i apostolstwa w życiu Sióstr Miłosierdzia, "W Nurcie Zagadnień Posoborowych" 15 (1983), p. 348.

52 After: A. Wach, Piękno życia kontemplacyjnego. Św. Teresa z Lisieux, “Życie Konsekrowane" 1 (1999), p. 63.

${ }^{53}$ Ibid. p. 64. 
with the idea of mercy and she gave herself entirely to God, following the example of His Divine Son, who humbled Himself on many occasions in order to gain the grace of redemption for everyone. She attempted to be weaker and smaller to best understand the logic of the merciful love of Jesus the Redeemer: St. Thérèse's life is a testimony, and a theological proof of the beauty of the contemplative life, led as a complete devotion to Christ. ${ }^{54}$

Saints have been people of prayer. They responded to the gift of redemption with piety in the school of prayer. Saints' lives are a testimony that prayer, particularly related to the Eucharist, contributes to gains in the grace of redemption, it strengthens the privilege of the adopted God's filiation, deepens participation in God's nature, increases faith, hope and love. Therefore, a Christian whose life concentrates on the mystery of redemption, ought to live in the light of the resurrected Christ, present in Eucharist.

In it, Jesus is active in the soul in a particular way, by becoming present there through His redemptive love. The intensity of the communion of love with Jesus increases as the unity and involvement of a Christian in the Eucharistic sacrifice grows. Because of this, a Christian may undertake the apostolic tasks for the world. They can fruitfully carry sanctity to the surrounding life, give a testimony of faith, hope and love. ${ }^{55}$

Eucharistic piety understood in this way requires of a Christian to persistently work on oneself through constant metanoia. Sometimes, spiritual heroism is necessary, which is faithfulness to the truth, good and service to others. Under difficult circumstances, we cannot escape heroism since there is no escape from the truth and good. ${ }^{56}$ The most important aspect of this heroism is love of God and neighbour: "It is a testimony of man through their intellect and will that there still exists a communion of persons, fulfilled in love, faith and hope, and because of their existence, truth and good, it is contemplation determining activity, which is metanoia, humanism and heroism". ${ }^{57}$

${ }^{54}$ Jan Paweł II, Divini amoris scientia. Apostolic letter of His Holiness Pope John Paul II Saint Thérèse of the Child Jesus and the Holy Face is proclaimed a Doctor of the Universal Church, No 11, "L'Osservatore Romano" (Polish Edition) 12 (1997), p. 35.

${ }_{55}$ Cf. S. Urbański, Eucharystia - źródłem kontemplacji i gorliwości apostolskiej, “Życie Konsekrowane" 2 (2004), pp. 44-53.

${ }^{56}$ Cf. M. Gogacz, Kontemplacja czy działanie, "W Nurcie Zagadnień Posoborowych" 14 (1981), p. 195.

${ }^{57}$ M. Gogacz, Kontemplacja czy działanie, “W Nurcie Zagadnień Posoborowych” 14 (1981), p. 195. 
There is no proper way of responding to the redemptive grace without drawing from the source of love, which is the triune God. We cannot truly love God and our neighbour without prayer. God is the source of love and the way which leads to this source of life is prayer. Love flows from prayer and also leads to it since it is its foundation and culmination at the same time. Prayer does not isolate us from the world, does not drag us away from our work nor does it forbid meeting other people but rather embraces us with its power and light. Prayer is seeking the truth about ourselves and the world.

Committing oneself to prayer is a task which is central to every Christian. One is a student of Christ as long as they want and can pray for the motive of love. By praying, man deeply comprehends that the love, which Jesus, the Son of God, manifested to us through His life, was the redemptive love. Jesus has become the fulfilment of God's plan for the redemptive love. ${ }^{58}$ He proclaimed love by the new law of the redeemed humankind. ${ }^{59}$ Prayer is the source of mercy. Jesus, knowing the moral weakness of human nature, in a way, extended in the Church, His forgiving mercy. He has commissioned the Church to forgive sins committed after the baptism, which takes places in the sacrament of penance. ${ }^{60}$

\section{Conclusion}

The Pelasgian deluge myth says that in the beginning there was love. The life of Ancient Greeks and Romans, particularly in the Homeric era and at the time of Seneca, indicates that every human seeks God and prays to their own God. The fulfilment of prayer through love was expected by all positive prayer codes of the culture of Antiquity. The intrinsic relation between prayer and love, examined in this article, finds its meaning and complement in the redemptive love, manifested to us by Jesus Christ.

Love understood in this way, manifested in Christ, was awaited by 'the ancient prophet', poet Virgil, who said that Novus ab integro nascitur ordo - " the new

${ }^{58}$ Cf. A. J. Nowak, Osoba konsekrowana, vol. III, p. 109.

59 "Christ is a sacrament, that is. a visible and effective sign of God's love to man, and simultaneously a way of the redeemed man to the house of Father". K. Kupiec, Być duchownym, p. 167.

${ }^{60}$ Cf. J. Stala, Rola znaków i symboli w katechezie o pokucie i Eucharystii, "Liturgia Sacra" 2 (2005), p. 311. 
order of the world is born" and its beginning will be "a Child born of a Virgin" (Virgil, Eclogues, 45 B.C).

It is this prophet whom John Paull II referred to in his message on the occasion of the $37^{\text {th }}$ World Day of Peace on 1 January 2004: "At the beginning of a New Year I wish to repeat to women and men of every language, religion and culture the ancient maxim: "Omnia vincit amor" (Love conquers all). ${ }^{61}$

\section{Bibliography}

Babiński M., "Actio" i “Contemplatio”, w prozie Seneki Młodszego, mps BKUL, Lublin 1984.

Bartnik C. S., Dogmatyka katolicka, vol. 1, Lublin 1999.

Cyprian, Saint, De Dominica oratione, 11: PL 4, 526 B.

Dec I., Uroczystość Chrystusa Króla, Bóg miłosierny i sprawiedliwy, "Wrocławski Przegląd Teologiczny" (2002) 1, p. 264.

Dyczewski L., Kościół katolicki wobec ubóstwa, "Zeszyty Naukowe Katolickiego Uniwersytetu Lubelskiego" 1-2 (1996), pp. 75-85.

Dziewiecki M., Komunikacja wychowawcza, Kraków 2004.

Fernandez C. F., Przebaczać i usprawiedliwiać, "Currenda” (1996) 4, pp. 645-648.

Ferreira de Farias J. J., Chrystocentryczny wymiar nadziei, “Communio" 1 (1991), pp. 42-57.

Geliusz, Aulus Gellius, Noctes Atticae XIII, 17,1.

Gocłowski T., Jedność kontemplacji i apostolstwa w życiu Sióstr Miłosierdzia, "W Nurcie Zagadnień Posoborowych" 15 (1983), pp. 341-356.

Gogacz M., Kontemplacja czy działanie, "W Nurcie Zagadnień Posoborowych" 14 (1981), pp. 195-206.

Gołąb M., Modlitwa adoracyjna (Wierność w modlitwie - wiernościa samemu Bogu), "Życie Konsekrowane" 1 (1999), pp. 39-46.

Granat W., Dogmatyka katolicka, t. IV, Lublin 1960.

Gryglewicz F., Problemy miłości w Nowym Testamencie, "Ruch Biblijny i Liturgiczny" (1974) 4-5, pp. 257-265.

Grzybek S., "Pod wieczór życia sądzeni będziemy z miłości", "Ruch Biblijny i Liturgiczny" (1979) 1-6, p. 73.

${ }^{61}$ Jan Paweł II, An ever timely commitment: teaching peace, Message of His Holiness Pope John Paul II for the celebration of the World Day of Peace 1 January 2004, "L'Osservatore Romano" (Polish Edition) 25 (2004) No 2, p. 7; Cf. S. Sojka Humanitas Hipokratesa w świetle rodziny i sztuki lekarskiej starożytnej Grecji, in: Odpowiednie dać rzeczy słowo, (eds.) J. Nowak, M. Rzepka, Tarnów 2016, p. 147. 
Gułkowski J., Miłość i czyn Karola Wojtyły - precyzacje antropologiczno-etyczne, "Novum" (1979) 1, pp. 32-41.

Heller M., 10.30 u Maksymiliana, Kraków 2014.

Hudzik J., Rozum - wolność - odpowiedzialność. Studium z historii idei w nowożytnej i współczesnej myśli filozoficznej, Lublin 2001.

Jan Paweł II, Divinia morisscientia. List apostolski wydany z okazji ogłoszenia św. Teresy od Dzieciątka Jezus i Najświętszego Oblicza Doktorem Kościoła powszechnego, No. 11, „L'Osservatore Romano” (Polish edition) 12 (1997), pp. 35-48.

Jan Paweł II, Zawsze aktualne zadanie wychowuje do pokoju, orędzie na XXXVII Światowy Dzień Pokoju 1 stycznia 2004 roku, "L’Osservatore Romano" (Polish edition) 25 (2004) No. 2, pp. 6-7.

Jezus Chrystus. Historia i Tajemnica, (eds.) W. Granat i E. Kopeć, Lublin 1982.

Królikowski J., Kupiec K., Święte posłanie. Z teologii kapłaństwa, Tarnów 2005.

Kudasiewicz J., Kult Ojca w Duchu i prawdzie a szczególna cześć Maryi, in: J. S. Gajek, K. Pek, Matka Jezusa pośród pielgrzymującego Kościoła, Warszawa 1993, p. 129.

Kupiec K., Być duchownym, in: J. Królikowski, K. Kupiec, Święte posłanie. Z teologii kapłaństwa, Tarnów 2005, pp. 153-215.

Kutnik J., Litania Loretańska, Kraków 1983.

Łach J., "Owocem Ducha jest miłość” (Ga 5,22), "Communio” (1995) 5, pp. 28-35.

Łach J., Obowiązek pojednania i miłości (Matthew 5:43-48), "Ruch Biblijny i Liturgiczny” (1986) 1-6, pp. 231-243.

Łach J., Relacja „złotej zasady postępowania” (Matthew 7:12) do nakazu miłości nieprzyjaciót (Matthew 5:43-48), "Ruch Biblijny i Liturgiczny" (1988) 6, p. 457-465.

Marion J. L., Communio w służbie kultury miłości, “Communio” (1992) 5, pp. 30-37.

Misiurek J., Historia i teologia polskiej duchowości katolickiej, vol. 3, Lublin 2001.

Nowak A. J., Osoba konsekrowana, vol. III: Ślub czystości, Lublin 1999.

Osewska E., Rozwój religijności człowieka ze szczególnym uwzględnieniem rozwoju modlitwy, in: Dzisiejszy katecheta. Stan aktualny i wyzwania, (ed.) J. Stala, Kraków 2002.

Ricciotti G., Życie Jezusa Chrystusa, Warszawa 1956.

Seneca L. A., Epistulae morales ad Lucilium De Providentia, Trans. L. Joachimowicz, Warszawa 1989, pp. 582-611.

Seneca L. A., Epistulae morales ad Serenum De Otio, Trans. L. Joachimowicz, Warszawa 1989, pp. 666-680.

Sojka S., Contemplatio et imitatio Christi, Chrystologiczny wymiar kontemplacji i naśladowania $w$ duchowości chrześcijańskiej wedtug współczesnego nauczania Kościoła. Kraków 2006.

Sojka S., Humanitas Hipokratesa w świetle rodziny i sztuki lekarskiej starożytnej Grecji, in: Odpowiednie dać rzeczy słowo, (eds.) J. Nowak, M. Rzepka, Tarnów 2016, pp. 124-149. 
Sojka S., LXXX Zjazd Polskiego Towarzystwa Filologicznego, „Vox Patrum” 4 (1984), part 6-7, pp. 470-474.

Sojka S., Modlitwa drogą do świętości, Tarnów 2011.

Sojka S., Obowiązek czci Boga na podstawie Psalmu 104, Lublin 2003.

Stala J., Rola znaków i symboli w katechezie o pokucie i Eucharystii, "Liturgia Sacra" 2 (2005), pp. 311-313.

Szafrański A. L., Wierzyć w Chrystusa i żyć Eucharystia, Bytom 1997.

Urbański S., Eucharystia - źródłem kontemplacji i gorliwości apostolskiej, “Życie Konsekrowane" 2 (2004), pp. 44-53.

Urbański S., Kontemplacja i działanie w życiu chrześcijanina, "Roczniki Teologiczne" 5 (1998), pp. 31-47.

Wach A., Piękno życia kontemplacyjnego. Św. Teresa z Lisieux, “Życie Konsekrowane” 1 (1999), pp. 57-66.

Walter M., Wiara dla przyszłości. Ilustrowany katechizm Kościoła katolickiego w słowach i obrazach, Warszawa 2000.

Winniczuk L., Ludzie, zwyczaje i obyczaje starożytnej Grecji i Rzymu, part. 1, Warszawa 1985.

Wójtowicz H., Rola modlitwy w mistyce w świetle wypowiedzi greckich Ojców Kościoła ze szczególnym uwzględnieniem wypowiedzi o modlitwie Orygenesa i Grzegorza z Nyssy, in: Mistyka w życiu człowieka, (ed.) W. Słomka, Lublin, 1980, pp. 113-123.

Wójtowicz H., Theoria i prasis u Orygenesa, "Roczniki Humanistyczne” 30 (1982), part 3, p. 65.

Zimoń D., Uczestnictwo wiernych we mszy św. w duchu liturgii na ziemiach polskich w XIX wieku, Katowice 2006. 